\title{
Povezanost pristupa poučavanju s percipiranom samoefikasnosti, zadovoljstvom poslom i životom te emocijama učitelja u osnovnoj školi
}

\author{
Tomislava Vidić \\ Osnovna škola Remete, Zagreb, Hrvatska \\ Dubravka Miljković \\ Sveučilište u Zagrebu, Učiteljski fakultet, Zagreb, Hrvatska
}

\begin{abstract}
Sažetak
Cilj je ovog istraživanja bio ispitati povezanost pristupa poučavanju sa samoefikasnosti, zadovoljstvom životom i poslom učitelja te u kojoj mjeri učitelji u osnovnoj školi doživljavaju pozitivne i negativne emocije. U istraživanju je sudjelovalo 254 učitelja iz osam zagrebačkih osnovnih škola. Rezultati su pokazali značajne povezanosti između pristupa poučavanja i dimenzija samoefikasnosti učitelja (angažiranost, strategije poučavanja, upravljanje razredom). Zadovoljstvo poslom značajno je povezano sa zadovoljstvom životom i pozitivnim emocijama. Negativne emocije značajno su negativno povezane sa zadovoljstvom poslom i životom. Učitelji koji imaju pristup poučavanja usmjeren na učenika statistički se značajno razlikuju od učitelja s pristupom usmjerenim na učitelja u dimenziji samoefikasnosti (strategije poučavanja) te češće doživljavaju pozitivne emocije: zainteresiranost, uzbuđenost i pozornost. Učitelji razredne nastave pokazali su veću angažiranost u odnosu na učitelje predmetne nastave. Učitelji s više od deset godina radnog iskustva statistički se značajno razlikuju od učitelja s manje godina radnoga iskustva u pristupima poučavanju i samoefikasnosti te češće doživljavaju ponos i budnost. S druge strane, učitelji s deset i manje od deset godina radnoga iskustva češće se osjećaju prestrašeno.
\end{abstract}

Ključne riječi: pristupi poučavanju, samoefikasnost, zadovoljstvo životom, zadovoljstvo poslom, emocije, učitelji u osnovnoj školi

\section{Uvod}

Kad učitelji raspravljaju o svojim problemima u radu s učenicima, najčešće ističu problem manjka ili nedostatka motivacije kod učenika (Beard i Senior, 1980). Pet je ključnih elemenata koji utječu na motivaciju učenika: učitelj, učenik, način rada, sadržaj rada i okruženje. Na primjer, učenik treba imati sposobnosti, interese i

Dubravka Miljković, Učiteljski fakultet Sveučilišta u Zagrebu, Savska cesta 77, 10000 Zagreb, Hrvatska. E-pošta: dubravka.miljkovic@ufzg.hr 
kvalitetno obrazovanje, a učitelj treba biti kvalitetno osposobljen kako bi mogao nadzirati i usmjeravati nastavni proces, mora biti posvećen svome poslu, odgovoran i inspirativan. Sadržaji poučavanja trebali bi biti suvremeni, poticajni, primjereni u sadašnjosti, ali i u učenikovoj budućnosti. Način rada treba biti inovativan, ohrabrujući, koristan, a okruženje pozitivno, individualizirano koliko je moguće te poticajno kako bi rezultat bio optimalan (Debnath, 2005; D'Souza i Maheshwari, 2010; Palmer, 2007). No, unatoč svemu, primjećuje se da ovi faktori nisu uvijek prisutni. Novija istraživanja upućuju na važnost uloge učitelja kao moderatora u nastavnom procesu. Način i pristupi poučavanju učitelja značajno utječu na način učenja učenika, a tako i na krajnji rezultat svakoga obrazovnog sustava (Ramsden, 1992; Trigwell i Prossser, 2004; Trigwell, Prosser i Watherhouse, 1999).

S obzirom na to da je primijećeno kako poučavanje učenika ne rezultira uvijek zadovoljavajućim ishodima, u posljednje je vrijeme značajno povećan broj istraživanja s ciljem ispitivanja kvalitete poučavanja (Postareff i Lindblom-Ylänne, 2008). Učiteljev pristup poučavanju (način kako radi) i njegove koncepcije o poučavanju u središtu su većeg broja istraživanja. Tako se pokazalo da su dubinski pristupi poučavanju povezani s boljim ishodima poučavanja (Marton i Säljö, 1976; Ramsden, 1992; Trigwell i Prosser, 1991; Van Rossum i Schenk, 1984), a način na koji učitelji poučavaju svoje učenike povezuje se s načinom na koji će učenik učiti (Ramsden, 1992; Trigwell i sur., 1999).

Trigwell, Prosser i Taylor (1994) su u svom istraživanju identificirali pet pristupa poučavanju: A: usmjerenost na učitelja kao prijenosnika informacija; B: usmjerenost na učitelja s namjerom ostvarivanja discipline; $\mathrm{C}$ : usmjerenost na interakcije učitelja i učenika s namjerom ostvarivanje discipline; D: usmjerenost na učenika s ciljem razvijanja discipline i $\mathrm{E}$ : pristup usmjeren na učenika $\mathrm{s}$ ciljem mijenjanja njegovih koncepcija. Sukladno su rezultatima istraživanja koja su uslijedila Trigwell i Prosser (2004) razvili upitnik za ispitivanje pristupa poučavanju koji uključuje karakteristike opisane u pristupima A (usmjerenost na učitelja) i E (usmjerenost na učenika).

Pristup usmjeren na učenika stavlja učenika u središte aktivnosti. Definira se kao način poučavanja u kojem se kod učenika potiče razumijevanje i tako mu se olakšava učenje. Učitelj s ovim pristupom zaokupljen je onim što učenik radi više nego time što on sam radi: ohrabruje učenika u učenju, stalno je dostupan, inicira raspravu, posvećuje dosta vremena u analizi učenikovih ideja te potiče komunikaciju tijekom poučavanja (Trigwell i sur., 1999).

Pristup usmjeren na učitelja opisan je kao način poučavanja u kojem su učenici više ili manje pasivni primatelji informacija; pretpostavlja se da učenik ne treba biti aktivan u procesu učenja i poučavanja. Učitelju s ovakvim pristupom u središtu je što on(a) čini; smatra da učenici imaju malo ili nimalo predznanja o sadržajima poučavanja, pa od njih očekuje tek bilježenje tih ex cathedra prezentiranih sadržaja (Kamber i Kwan, 2000; Trigwell i Prosser, 1996a, 1996b; Trigwell i sur., 1999). 
Pristup koji će učitelji prihvatiti povezan je s njihovim koncepcijama o poučavanju (Trigwell i Prosser, 1996b) i njihovim percepcijama o okruženju u kojem poučavaju (Prosser i Trigwell, 1997). Učitelji koji smatraju da je učenje gomilanje informacija, smatraju i da je poučavanje proces prijenosa informacija učenicima. S druge strane, učitelji koji misle da je učenje proces mijenjanja učenikovih spoznaja, smatraju da je svrha poučavanja pomoći učeniku u razvoju i mijenjanju njegovih dotadašnjih spoznaja (Prosser i Trigwell, 1998; Trigwell i sur., 1999). Unatoč sličnostima koje se uočavaju između učiteljeva pristupa poučavanju i njegovih koncepcija o poučavanju potrebno je naglasiti da one nisu uvijek iste. Razlike između pristupa poučavanju (onoga što učitelj radi) i njegovih koncepcija (onoga što misli o poučavanju) nerijetko proizlaze iz njegovih percepcija o okruženju u kojem radi. Naime, učitelj može misliti da je određena metoda poučavanja primjerenija prilikom učenja novih sadržaja, ali zbog loših materijalnih uvjeta (opća neopremljenost škole, nedostatna nastavna sredstva, neadekvatan prostor u kojem radi) nije u mogućnosti realizirati nastavu na način na koji želi.

Istraživanje percepcija učiteljske uloge $\mathrm{u}$ odgojno-obrazovnom procesu provedeno u Hrvatskoj na uzorku 3468 učitelja (Pavin, Rijavec i Miljević-Riđički, 2005) pokazalo je da učitelji razredne nastave izražavaju znatno veći stupanj slaganja s pristupom usmjerenim na učenika, a predmetni nastavnici pristup usmjeren na nastavnika. Uočena je i temeljna razlika s obzirom na pristup poučavanju; oni koji više izražavaju pristup usmjeren na učenika smatraju kako je najbitnije usmjeriti se na poticanje logičkog razmišljanja i kreativnosti kod učenika, dok oni usmjereni na sebe smatraju kako je njihova najvažnija zadaća što kvalitetnije prenijeti znanje učenicima. Istraživanje koje je provela Pavin Ivanec (2008) na 372 gimnazijska nastavnika i 573 učenika 4. razreda gimnazije pokazalo je da je među nastavnicima čiji je pristup poučavanju u većoj mjeri usmjeren na učenike i više učenika koji uče dubinski, dok je među nastavnicima koji su u manjoj mjeri usmjereni na učenike i više učenika koji uče površinski.

U skladu s time, očekivano je i da će učitelji usmjereni na učenike iskazivati i višu razinu samoefikasnosti, tj. vjerovanja da mogu uspjeti u nekoj aktivnosti usprkos mogućim preprekama (Bandura, 1997), odnosno, vjerovanja u vlastite sposobnosti poučavanja i motiviranja učenika neovisno o učenikovim sposobnostima i obiteljskoj situaciji (Ashton i Webb, 1986). Autori navode kako učitelji s niskim osjećajem samoefikasnosti sumnjaju u svoje sposobnosti da utječu na učenje učenika, pa izbjegavaju aktivnosti za koje smatraju da su zahtjevne. S druge strane, učitelji s visokim osjećajem samoefikasnosti vjeruju da su sposobni pozitivno utjecati na svoje učenike, a moguće će ih prepreke samo dodatno motivirati. Viša samoefikasnost dovodi do većeg ulaganja truda i upornosti što dovodi do boljeg rada i rezultata rada, a posljedično do veće samoefikasnosti. Tijekom vremena taj se proces stabilizira i postaje relativno trajno uvjerenje (Tschannen-Moran, Woolfolk Hoy i Hoy, 1998). Učitelji s visokim osjećajem samoefikasnosti postavljaju više ciljeve i bolje su organizirani u radu (Allinder, 
1994). Oni su otvoreniji za nove ideje i pristupe, spremniji su eksperimentirati s novim načinima rada, a sve s ciljem da približe učenicima nove sadržaje učenja (Stein i Wang, 1988). Također, učitelji s višim stupnjem samoefikasnosti manje kritiziraju učenike koji pogriješe u radu (Ashton i Webb, 1986), spremniji su više vremena posvetiti učenicima koji sporije svladavaju sadržaje učenja (Gibson i Dembo, 1984), pokazuju viši entuzijazam u poučavanju (Allinder, 1994) te su predaniji poslu u odnosu na ostale učitelje (Coladarci, 1992). Također, učiteljev osjećaj samoefikasnosti povezan je s učeničkim postignućima (Ashton i Webb, 1986; Ross, 1992), motivacijom učenika (Midgley, Feldlaufer i Eccles, 1989) i osjećajem samoefikasnosti kod učenika (Anderson, Greene i Loewen, 1988).

Unatoč važnosti istraživanja samoefikasnosti učitelja ona su u Hrvatskoj izrazito zanemarena, odnosno dominiraju istraživanja samoefikasnosti učenika $i$ studenata. Jedno od ranijih istraživanja (Vidić, 2009), provedeno na uzorku 163 učitelja razredne nastave, pokazalo je da učitelji najbolje percipiraju svoju samoefikasnost $\mathrm{u}$ upravljanju razredom, a najmanje u traženju podrške ravnatelja, a što je važna komponenta radne motivacije i zadovoljstva poslom općenito (Slišković, Burić i Knežević, 2016).

Zadovoljstvo poslom jedna je od komponenti zadovoljstva životom (Andrews i Withey, 1976; prema Pavot i Diener, 1993), tj. mjere u kojoj pojedinci ocjenjuju kvalitetu vlastita života na temelju njima važnih kriterija (Shin i Johnson, 1978). Danas se istraživanju zadovoljstva životom (poslom) pristupa s aspekta kognitivne komponente subjektivne dobrobiti (sreće). U metaanalizi istraživanja koju su proveli Lyubomirsky, King i Diener (2005) pokazalo se da su sretniji ljudi spremniji preuzeti rizik, otvorenijeg su uma, kreativniji, uspješniji u različitim područjima života (posebno u poslovima u kojima je važna interakcija s drugima), a zadovoljstvo životom i pozitivan stav utječu na njihovu efikasnost. Istražujući zadovoljstvo životom učitelja Duckworth, Quinn i Seligman (2009) ustanovili su da je zadovoljstvo životom najbolji prediktor efikasnosti učitelja: oni zadovoljniji svojim životom vještiji su u radu s učenicima, a njihov entuzijazam i energičnost prelaze na njihove učenike. Zanimljivo istraživanje provedeno u Hrvatskoj pokazalo je da su učitelji zadovoljniji životom ako imaju pozitivna radna iskustva, dok nisko zadovoljstvo životom pokazuju učitelji s dominantnim negativnim radnim iskustvom (Miljković i Rijavec, 2007). Istraživanje subjektivne dobrobiti i radnih orijentacija, provedeno u Hrvatskoj na uzorku 249 učitelja razredne nastave (Miljković, Jurčec i Rijavec, 2016), pokazalo je da radne orijentacije učitelja utječu na njihovu subjektivnu dobrobit, tj. da učitelji koji su motivirani za posao prvenstveno zbog toga što obavljaju društveno koristan rad pokazuju veće zadovoljstvo životom. S druge strane, učitelji koji su usmjereni na posao, ali stavljaju fokus na financijsku nagradu, te učitelji koji su usmjereni na karijeru (postignuća i mogućnosti napredovanja) pokazuju niži stupanj subjektivne dobrobiti. Općenito se smatra da su zadovoljni učitelji ujedno i odaniji školi u kojoj rade (Matzler i Renzl, 2006), otvoreniji su prema promjenama u načinu i sadržaju rada (Bryk i Schneider, 2002), podržavaju 
inovativnu školsku klimu (Moolenaar i Sleegers, 2010) te imaju kvalitetnije odnose s učenicima, roditeljima i suradnicima (Van Maele i Van Houtte, 2012).

Istražujući uzroke nezadovoljstva poslom učitelja, McClay ističe da se od učitelja očekuju da budu dvostruko bolji, dvostruko više altruistični, dvostruko fleksibilniji i upola manje zabrinuti zbog plaće (McClay, 1995; prema Marlow, Inman i Betancourt-Smith, 1996). Marlow i suradnici identificiraju pet glavnih uzroka učiteljeva nezadovoljstva: učenici, emocionalni aspekti/sagorijevanje na poslu, nedostatak poštovanja, radni uvjeti, plaća/izostanak nagrada. Učenici mogu biti uzrok nezadovoljstva učitelja zbog disciplinskih problema, lošeg odnosa prema radu i učenju. Izostanak ispunjenja, dosada koja se javlja zbog svakodnevne rutine, stres i frustriranost predstavljaju faktore koji utječu na emocionalno stanje učitelja te mogu dovesti do pojave sagorijevanja na poslu. Nedostatak poštovanja najviše je vidljiv kroz neprepoznavanje rada u zajednici, lokalnoj sredini. Nedostatak poštovanja u uskoj je vezi s gubitkom ili smanjenjem autoriteta te direktno utječe na rad učitelja s učenicima. Uvjeti rada su faktor koji obuhvaća broj učenika u razredu, izvannastavne obveze učitelja (administrativni poslovi, sastanci), nedovoljnu količinu ili kvalitetu sredstava za rad. Visina plaće je, prema nekim istraživanjima, glavni uzrok zbog kojeg učitelji napuštaju posao (Ingersoll, 2003; Marlow i sur., 1996).

No, iako brojni autori ističu prisutnost nezadovoljstva poslom učitelja, rezultati ranijih istraživanja TIMSS koja se odnose na Hrvatsku pokazuju suprotno. Od 47 država koje su 2011. godine sudjelovale u istraživanju TIMSS Hrvatska je bila na prvom mjestu prema zadovoljstvu poslom učitelja u osnovnoj školi, a 2015. godine na jedanaestom mjestu, gdje je čak $64 \%$ ispitivanih učitelja izjavilo da je vrlo zadovoljno svojim poslom, $35 \%$ je zadovoljno, a $1 \%$ učitelja nije zadovoljan svojim poslom (TIMSS i PIRLS, 2016).

Slični su rezultati dobiveni i u drugim istraživanjima u Hrvatskoj i Sloveniji. Istraživanje koje su provele Rijavec i suradnice pokazalo je da je većina ispitivanih učitelja intrinzično motivirana, svoj posao smatraju pozivom te pokazuju veće zadovoljstvo poslom (Rijavec, Pečjak, Jurčec i Gradišek, 2016).

Osim kognitivne, subjektivna dobrobit ima i afektivnu komponentu: ugodna $\mathrm{i}$ neugodna stanja i emocije pojedinca (Diener i Emmons, 1984). Biti učitelj, kao i baviti se poučavanjem, znači obavljati emocionalan posao (Hargreaves, 1998), odnosno emocije se smatraju dijelom učiteljskog poziva (Sutton i Wheatley, 2003). Unatoč tome, istraživanja učiteljskih emocija prisutna su tek posljednjih dvadesetak godina. Od tada je ustanovljeno da su emocije učitelja prediktori njegova ponašanja u učionici, utječu na način i kvalitetu predavanja, a posljedično i na učenička postignuća (Frenzel, 2014), povezane su s dobrobiti učitelja (Chang, 2009; Keller, Chang, Becker, Goetz i Frenzel, 2014), njihovom efikasnosti (Sutton, 2005), učenikovim emocijama i motivacijom (Becker, Goetz, Morger i Ranellucci, 2014; Frenzel, Götz, Lüdtke, Pekrun i Sutton, 2009) te učenjem i obrazovnim postignućima 
učenika (Beilock, Gunderson, Ramirez i Levine, 2010; Pekrun, Goetz, Titz i Perry, 2002).

Istraživanja pokazuju da učitelji tijekom rada u učionici doživljavaju različite emocije, kao na primjer užitak (Sutton i Wheatley, 2003), ponos (Darby, 2008), ljutnju i frustriranost (Sutton, 2007), krivnju (Hargreaves i Tucker, 1991) i anksioznost (Beilock i sur., 2010; Keller i sur., 2014). Većina je provedenih istraživanja kvantitativnog tipa; tek manji broj kvalitativnih istraživanja ističe da je užitak najstalnija pozitivna emocija, a ljutnja najčešće doživljena negativna emocija učitelja tijekom poučavanja (Frenzel, 2014). Na emocije učitelja najviše utječu upravo ponašanja učenika tijekom nastave. Na primjer, ranija istraživanja pokazuju da odlični i visoko motivirani učenici predstavljaju uzrok pozitivnih emocija učitelja (Frenzel i sur., 2009; Hargreaves, 2000). Pokazalo se da je motiviranost učenika povezana s emocijama učitelja i to neovisno o učeničkim kognitivnim sposobnostima i postignućima; učitelji vole poučavati učenike koji se trude i marljivo rade (Biddle i Goudas, 1997). S druge strane, učenikovo loše ponašanje ključni je faktor koji utječe na stvaranje negativnih emocija učitelja (Sutton i Wheatley, 2003). Učenici koji ometaju nastavu i ne poštuju razredna pravila neposredno utječu na održavanje nastave, ugrožavaju ostvarivanje postavljenih nastavnih ciljeva te takvo ponašanje ima dugoročan utjecaj na psihološku dobrobit i emocionalnu iscrpljenost učitelja (Chang, 2013). Ponekad su učitelji uvjereni da osjećati ljutnju nije u skladu s njihovim profesionalnim identitetom u učionici, pa radije iskazuju frustriranost nego ljutnju (Sutton, 2007). No, ljutnja zaista može prijeći u frustriranost upravo zbog toga što se učitelji mogu osjećati bespomoćno prilikom rješavanja disciplinskih problema učenika (Sutton, 2007). Zbog toga Chang (2009) navodi da učitelji, u usporedbi s pojedincima u ostalim zanimanjima, doživljavaju viši stupanj emocionalne iscrpljenosti. Emocije doživljene u odnosu s učenicima i roditeljima, kao i doživljaj razočaranosti u obrazovni sustav, ostvaruju značajne samostalne doprinose u objašnjenju anksioznih, depresivnih i somatizacijskih simptoma kod učitelja (Macuka, Burić i Slišković, 2017). S druge strane, pozitivne emocije imaju pozitivne posljedice na svakodnevni život u učionici; učiteljica koja pokazuje entuzijazam za svoj rad i za ono što poučava prenosi svoj entuzijazam i na učenike (Miljković i Rijavec, 2009).

Cilj je ovog istraživanja bio ispitati u kojoj su mjeri, kod učitelja osnovne škole, izraženi pristupi poučavanju (usmjerenost na učenika i usmjerenost na sebe), te koliko su ti pristupi povezani s percepcijom vlastite samoefikasnost, životnim i poslovnim zadovoljstvom te doživljavanjem pozitivnih i negativnih emocija $-\mathrm{s}$ obzirom na radno mjesto učitelja (razredna ili predmetna nastava) i s obzirom na radni staž (deset i manje od deset godina; više od deset godina).

Na temelju su dosadašnjih istraživanja formulirane sljedeći problemi i hipoteze:

1. Razlikuju li se učitelji s obzirom na pristup poučavanju, u samoefikasnosti, zadovoljstvu poslom i životom te u kojoj mjeri doživljavaju pozitivne odnosno negativne emocije. Hipoteza je da će oni koji su u poučavanju 
usmjereni na učenika pokazati veću samoefikasnost, zadovoljstvo poslom i životom te da će doživljavati više pozitivnih, a manje negativnih emocija u odnosu na učitelje s pristupom poučavanja usmjerenim na učitelja.

2. Razlikuju li se učitelji razredne i predmetne nastave po svojem pristupu poučavanju i drugim promatranim varijablama. Pretpostavlja se da će učitelji razredne, u odnosu na učitelje predmetne nastave, više iskazivati pristup poučavanja usmjeren na učenika, bit će samoefikasniji, zadovoljniji poslom i životom te će doživljavati više pozitivnih emocija.

3. Razlikuju li se učitelji s više od deset godina radnoga iskustva od onih s deset i manje godina učiteljskoga staža. Pretpostavka je da će iskusniji učitelji u svom poučavanju biti više usmjereni na učenike, višom će percipirati svoju samoefikasnost, bit će zadovoljniji poslom i životom i više će doživljavati pozitivnih nego negativnih emocija.

\section{Metoda}

\section{Ispitanici i postupak}

Istraživanje je provedeno u osam osnovnih škola Grada Zagreba popunjavanjem upitnika na početku sjednice učiteljskog vijeća. Istraživanju je pristupilo 278 učitelja razredne i predmetne nastave što predstavlja $75.34 \%$ zaposlenih učitelja u tim školama. Dio je upitnika isključen iz daljnje obrade zbog pogrešnog ili nepotpunog ispunjavanja, pa konačni uzorak čini 254 sudionika. Od ukupnog je broja $89.8 \%$ ženskog $(N=228)$, a $10.2 \%$ muškog roda $(N=26)$. $\mathrm{S}$ obzirom na mali broj muškaraca, rodne se razlike nisu analizirale. Učitelji razredne nastave čine $47.6 \%$ uzorka $(N=121)$, a $52.4 \%$ je učitelja predmetne nastave $(N=$ 133). Prosječno je radno iskustvo sudionika 15.07 godina. Podjelom s obzirom na duljinu radnoga staža dobivene su dvije skupine: oni s deset i manje godina radnog staža $(N=98,38.6 \%)$ te oni s više od 10 godina radnoga staža $(N=156,61.4 \%)$.

\section{Instrumenti}

U uvodnom su dijelu ispitivanja prikupljeni demografski podaci o sudionicima; rod, godine radnoga staža u struci, radno mjesto ispitanika (razredna ili predmetna nastava).

Upitnik za ispitivanje pristupa poučavanju (engl. Approaches to Teaching Inventory, ATI; Trigwell, Prosser i Ginns, 2005) sastoji se od 22 čestice, a mjeri dvije dimenzije pristupa: pristup usmjeren na učitelja/prijenos informacija (primjer tvrdnje: Poučavanje organiziram na način koji će učenicima pomoći da što bolje riješe zadatke za provjeru) te pristup usmjeren na učenika (primjer tvrdnje: $U$ poučavanju namjerno provociram razgovore $i$ rasprave učenika). Svaka se 
dimenzija sastoji od 11 tvrdnji. Učitelji su na skali od pet stupnjeva od 1 (nikad) do 5 (uvijek) trebali procijeniti koliko se slažu s pojedinom tvrdnjom. Pouzdanost tipa unutarnje konzistencije iznosi .72 za pristup usmjeren na učitelja i .76 za pristup usmjeren na učitelja, što je u skladu s ranijim istraživanjima (Prosser i Trigwell, 1997; Trigwell i sur., 1994).

Upitnik za ispitivanje samoefikasnosti učitelja (engl. Teachers' Sense of Efficacy Scale, TSES; Tschannen-Moran i Woolfolk Hoy, 2001) sastoji se od 12 tvrdnji, a mjeri tri dimenzije: učenički angažman (primjer tvrdnje: Koliko možete motivirati slabije motivirane učenike za sudjelovanje u školskom radu?), strategije poučavanja (primjer tvrdnje: Koliko uspješno možete osmisliti zanimljiva pitanja za svoje učenike?) te upravljanje razredom (primjer tvrdnje: Koliko uspješno možete kontrolirati ometajuća ponašanja učenika u učionici?). Svaka dimenzija sadrži četiri tvrdnje koje su ispitanici procjenjivali na skali od pet stupnjeva od 1 (nimalo) do 5 (jako puno). Pouzdanost tipa unutarnje konzistencije iznosi .69 za angažiranost, .72 za strategije poučavanja i .86 za dimenziju upravljanje razredom što je slično rezultatima ranijih istraživanja (Tschannen-Moran i Woolfolk Hoy, 2001).

Upitnik zadovoljstva životom (engl. The Satisfaction With Life Scale; Diener, Emmons, Larsen i Griffin, 1985) sastoji se od pet tvrdnji. Ispitanici su tvrdnje (primjer tvrdnje: Zadovoljna sam svojim životom) procjenjivali na skali od pet stupnjeva od 1 (uopće ne) do 5 (potpuno). Pouzdanost tipa unutarnje konzistencije iznosi .79.

Upitnik za ispitivanje pozitivnih i negativnih emocija (engl. Positive and Negative Affect Scales, PANAS; Watson, Clark i Tellegen, 1988) uključuje 20 emotivnih stanja; 10 pozitivnih (npr. zainteresirano, poletno, ponosno...) i 10 negativnih (živčano, posramljeno, nesretno...). Ispitanici su procjenjivali koliko su se općenito tako osjećali u životu. Ponuđene su procjene na ljestvici od 1 (uopće ne ili vrlo malo) do 5 (jako). Pouzdanost tipa unutarnje konzistencije iznosi $.87 \mathrm{za}$ pozitivne i .90 za negativne emocije, što je u skladu s rezultatima ranijih istraživanja (Watson i sur., 1988).

Opće zadovoljstvo poslom mjereno je jednom tvrdnjom: Općenito gledajući, zadovoljan/na sam svojim poslom (Scarpello i Campbell, 1983), koju su ispitanici procjenjivali na Likertovoj skali od pet stupnjeva (od uopće se ne odnosi na mene do u potpunosti se odnosi na mene).

\section{Rezultati}

$\mathrm{Na}$ rezultatima upitnika za ispitivanje pristupa poučavanju provedena je faktorska analiza metodom glavnih komponenti uz Varimax rotaciju. Primijenjen je Kaiser-Meyer-Olkin test adekvatnosti uzorkovanja koji je iznosio .83 (Bartlettov test sfericiteta $\chi_{d f 210}^{2}=1155.74, p=.00$ ), što potvrđuje pogodnost matrice korelacija za faktorizaciju. Faktorskom analizom ekstrahirana su dva glavna faktora prema 
Kaiser-Guttmanovom kriteriju s karakterističnim korijenom većim od 1, koja ukupno objašnjavaju $31.20 \%$ varijance rezultata. Izračunata je pouzdanost tipa unutarnje konzistencije (Cronbach alpha) za svaku dimenziju.

Da bi se utvrdila faktorska struktura upitnika TSES, provedena je faktorska analiza metodom glavnih komponenata s Varimax rotacijom. Kaiser-Meyer-Olkin testom prikladnosti utvrđeno je da su podaci prikladni za faktorizaciju $(\mathrm{KMO}=.87$, Bartlettov test sfericiteta $\chi_{d f 66}^{2}=1025.25, p=.00$ ). Korištena je metoda glavnih komponenti na tri faktora koja ukupno objašnjavaju $60.57 \%$ varijance.

U Tablici 1. prikazani su deskriptivni statistički pokazatelji pojedinih varijabli.

Tablica 1.

Deskriptivni statistički pokazatelji pristupa poučavanju, samoefikasnosti učitelja, njihova zadovoljstva životom i poslom te doživljenih emocija $(N=254)$

\begin{tabular}{|c|c|c|c|c|c|c|c|c|}
\hline Varijabla & $\begin{array}{c}\text { Broj } \\
\text { tvrdnji }\end{array}$ & Min & Max & $M$ & $S D$ & Asim. & Spljošt. & $\alpha$ \\
\hline \multicolumn{9}{|l|}{ Pristupi poučavanju } \\
\hline $\begin{array}{l}\text { usmjerenost na } \\
\text { učitelja }\end{array}$ & 10 & 2.50 & 5.00 & 4.12 & .40 & -0.239 & 0.651 & .72 \\
\hline $\begin{array}{l}\text { usmjerenost na } \\
\text { učenika }\end{array}$ & 11 & 2.73 & 4.91 & 4.16 & .36 & -0.348 & 0.170 & .76 \\
\hline \multicolumn{9}{|l|}{$\begin{array}{l}\text { Samoefikasnost } \\
\text { učitelja }\end{array}$} \\
\hline angažiranost & 4 & 2.75 & 5.00 & 4.00 & .47 & -0.141 & 0.062 & .69 \\
\hline strategije poučavanja & 4 & 2.75 & 5.00 & 4.21 & .49 & -0.497 & -0.250 & .72 \\
\hline upravljanje razredom & 4 & 2.00 & 5.00 & 4.22 & .55 & -0.513 & 0.389 & .86 \\
\hline Zadovoljstvo životom & 5 & 2.40 & 5.00 & 3.99 & .49 & -0.167 & 0.367 & .79 \\
\hline Zadovoljstvo poslom & 1 & 2.00 & 5.00 & 4.13 & .65 & -0.488 & 0.790 & - \\
\hline Pozitivne emocije & 10 & 2.40 & 5.00 & 3.83 & .52 & -0.209 & -0.371 & .87 \\
\hline Negativne emocije & 10 & 1.00 & 3.80 & 1.71 & .56 & 1.024 & 1.146 & .89 \\
\hline
\end{tabular}

Prema podacima dobivenim na cjelokupnom uzorku vidljivo je da učitelji tek neznatno više prihvaćaju pristup usmjeren na učenika nego pristup usmjeren na učitelja. U dimenzijama samoefikasnosti učitelja učitelji najbolje procjenjuju dimenziju upravljanje razredom, a nešto slabije dimenziju angažiranost. Analiza odgovora na pojedine tvrdnje pokazala je da učitelji visokima ocjenjuju tvrdnje koje se odnose na njihov neposredan rad s učenicima, uvođenje razrednih pravila ili, primjerice, kontroliranje ometajućih ponašanja u učionici. Najniže su procijenjene tvrdnje koje se odnose na suradnju s roditeljima i uvođenje alternativnih metoda rada. Rezultati pokazuju da učitelji pokazuju veće zadovoljstvo poslom nego zadovoljstvo životom, te češće doživljavaju pozitivne nego negativne emocije. Prema rezultatima ovog istraživanja najčešće su doživljene pozitivne emocije zainteresiranost $(M=$ 4.18, $S D=0.67)$, aktivnost $(M=4.03, S D=0.75)$, ponos $(M=4.02, S D=0.75)$, a najmanje poletnost $(M=3.65, S D=0.82)$ te uzbuđenost $(M=3.20, S D=0.82)$. 
Najčešće su doživljene negativne emocije uznemirenost $(M=2.16, S D=0.90)$, nervoza $(M=1.99, S D=0.91)$, razdražljivost $(M=1.94, S D=0.88)$, a najrjeđe posramljenost $(M=1.29, S D=0.56)$ te neprijateljsko raspoloženje $(M=1.25, S D=$ 0.53). No, važno je istaknuti da većina ispitivanih učitelja negativne emocije doživljava jako malo do umjereno često.

Za utvrđivanje povezanosti između varijabli izračunati su Pearsonovi koeficijenti korelacije prikazani u Tablici 2. U skladu s očekivanjima, pristup usmjeren na učenika pozitivno je povezan sa svim dimenzijama samoefikasnosti, sa zadovoljstvom životom i poslom te pozitivnim emocijama, a negativno je povezan $\mathrm{s}$ negativnim emocijama. Općenito su pozitivne emocije pozitivno povezane sa svim ispitivanim varijablama, dok su negativne emocije negativno povezane sa zadovoljstvom poslom i životom.

Tablica 2.

Koeficijenti korelacija pristupa poučavanju, samoefikasnosti učitelja, njihova zadovoljstva životom i poslom te doživljenih emocija

\begin{tabular}{|c|c|c|c|c|c|c|c|c|c|}
\hline & 1 & 2 & 3 & 4 & 5 & 6 & 7 & 8 & 9 \\
\hline $\begin{array}{l}\text { Pristup usmjeren } \\
\text { na učitelja (1) }\end{array}$ & - & & & & & & & & \\
\hline $\begin{array}{l}\text { Pristup usmjeren } \\
\text { na učenika (2) }\end{array}$ & $.46^{* *}$ & - & & & & & & & \\
\hline $\begin{array}{l}\text { Angažiranost } \\
\text { (3) }\end{array}$ & $.34^{* *}$ & $.46^{* *}$ & - & & & & & & \\
\hline $\begin{array}{l}\text { Strategije } \\
\text { poučavanja (4) }\end{array}$ & $.34^{* *}$ & $.59^{* *}$ & $.60^{* *}$ & - & & & & & \\
\hline $\begin{array}{l}\text { Upravljanje } \\
\text { razredom (5) }\end{array}$ & $.33^{* *}$ & $.25^{* * *}$ & $.37^{* *}$ & $.34^{* *}$ & - & & & & \\
\hline $\begin{array}{l}\text { Zadovoljstvo } \\
\text { životom (6) }\end{array}$ & .11 & $.21^{* * *}$ & $.21^{* *}$ & $.17^{* *}$ & $.32^{* *}$ & - & & & \\
\hline $\begin{array}{l}\text { Zadovoljstvo } \\
\text { poslom (7) }\end{array}$ & .05 & $.14^{*}$ & $.25^{* *}$ & $.21^{* *}$ & $.18^{* *}$ & $.47^{* *}$ & - & & \\
\hline $\begin{array}{l}\text { Pozitivne } \\
\text { emocije ( } 8)\end{array}$ & $.27^{* *}$ & $.40^{* *}$ & $.35^{* *}$ & $47^{* *}$ & $.36^{* *}$ & $.45^{* *}$ & $.42^{* * *}$ & - & \\
\hline $\begin{array}{l}\text { Negativne } \\
\text { emocije (9) }\end{array}$ & -.03 & -.11 & -.12 & -.08 & -.24 & $-.41^{* *}$ & $-.30^{* * *}$ & $-.33^{* *}$ & - \\
\hline
\end{tabular}

${ }^{*} p<.05 ;{ }^{* *} p<.01$.

Prvi je problem istraživanja bio ispitati razlikuju li se učitelji, s obzirom na pristup poučavanju, u samoefikasnosti, zadovoljstvu poslom i životom te u kojoj mjeri doživljavaju pozitivne odnosno negativne emocije. Uzorak ispitanika podijeljen je u dvije skupine pomoću dobivenih srednjih vrijednosti svakog ispitanika na oba faktora. Ispitanici su grupirani s obzirom na kojem od tih dvaju faktora imaju veću vrijednost. Na taj su način formirane dvije skupine ispitanika - 
učitelji s pristupom poučavanja usmjerenim na učenika te učitelji s pristupom usmjerenim na učitelja. Dobiveni su rezultati prikazani u Tablici 3.

Tablica 3.

Razlike između učitelja s pristupom usmjerenim na učitelja i s pristupom usmjerenim na učenika

\begin{tabular}{lccccc}
\hline & \multicolumn{2}{c}{$\begin{array}{c}\text { Pristup usmjeren na } \\
\text { učitelja } \\
(N=133)\end{array}$} & \multicolumn{2}{c}{$\begin{array}{c}\text { Pristup usmjeren na } \\
\text { učenika } \\
(N=120)\end{array}$} & \multirow{2}{*}{$t$ - test } \\
\cline { 2 - 5 } & $M$ & $S D$ & $M$ & $S D$ & \\
\hline Samoefikasnost učitelja & & & & & \\
\hline angažiranost & 4.00 & 0.49 & 4.00 & 0.45 & 0.28 \\
strategije poučavanja & 4.13 & 0.50 & 4.30 & 0.47 & $-2.65^{*}$ \\
upravljanje razredom & 4.27 & 0.52 & 4.17 & 0.58 & 1.45 \\
\hline Zadovoljstvo životom & 3.94 & 0.48 & 4.05 & 0.50 & -1.84 \\
\hline Zadovoljstvo poslom & 4.12 & 0.59 & 4.15 & 0.71 & -0.36 \\
\hline Pozitivne emocije ${ }^{1}$ & 3.78 & 0.53 & 3.89 & 0.49 & -1.78 \\
\hline zainteresiranost & 4.07 & 0.69 & 4.29 & 0.63 & $-2.67^{*}$ \\
uzbuđenost & 3.07 & 0.83 & 3.33 & 0.79 & $-2.60^{*}$ \\
pozornost & 3.83 & 0.73 & 4.02 & 0.70 & $-2.03^{*}$ \\
\hline Negativne emocije & 1.74 & 0.54 & 1.67 & 0.58 & 0.91 \\
\hline
\end{tabular}

${ }^{*} p<.05 ;{ }^{1}$ prikazuju se pojedinačno samo one emocije na kojima je dobivena značajna razlika

Rezultati pokazuju da učitelji koji imaju pristup poučavanja usmjeren na učenika gotovo sve dimenzije procjenjuju višim vrijednostima, a statistički se značajno razlikuju u samoefikasnosti, $\mathrm{tj}$. dimenziji strategije poučavanja te $\mathrm{u}$ pozitivnim emocijama: zainteresiranost, uzbuđenost i pozornost. Dobiveni su rezultati u skladu opisom pristupa poučavanju usmjerenom na učenika kao pristupa u kojem učitelji nastoje proširiti znanja učenika te im stalno pokušavaju pomoći u procesu stjecanja znanja.

Drugi se problem odnosio na razlike između učitelja razredne i predmetne nastave. U Tablici 4. prikazane su dobivene srednje vrijednosti, pripadajuće standardne devijacije te rezultati $t$-testa.

Dobiveni rezultati pokazuju da učitelji razredne nastave u odnosu na učitelje predmetne nastave višim vrijednostima procjenjuju gotovo sve dimenzije, ali se statistički značajno razlikuju samo u dimenziji angažiranost.

U potrazi za odgovorom na treći problem uzorak je podijeljen u dvije skupine, s obzirom na duljinu radnoga staža. Prvu su skupinu činili ispitanici s 10 ili manje od 10 godina radnoga iskustva, a drugu skupinu ispitanici s više od 10 godina radnoga iskustva. Podaci o dobivenim srednjim vrijednostima, standardnim devijacijama te rezultati $t$-testa prikazani su u Tablici 5. 
Tablica 4.

Razlike između učitelja razredne i predmetne nastave

\begin{tabular}{lccccc}
\hline & \multicolumn{2}{c}{$\begin{array}{c}\text { Razredna nastava } \\
\end{array}$} & \multicolumn{2}{c}{$\begin{array}{c}\text { Predmetna nastava } \\
(N=121)\end{array}$} & \multirow{2}{*}{$t$ - test } \\
\cline { 2 - 5 } & $M$ & $S D$ & $M$ & $S D$ & \\
\hline Pristupi poučavanju & & & & & \\
\hline usmjeren na učitelja & 4.09 & 0.40 & 4.14 & 0.41 & -0.92 \\
usmjeren na učenika & 4.16 & 0.35 & 4.15 & 0.36 & 0.08 \\
\hline Samoefikasnost učitelja & & & & & \\
\hline angažiranost & 4.11 & 0.43 & 3.91 & 0.49 & $3.40^{*}$ \\
strategije poučavanja & 4.23 & 0.51 & 4.19 & 0.48 & 0.68 \\
upravljanje razredom & 4.26 & 0.53 & 4.19 & 0.56 & 1.00 \\
\hline Zadovoljstvo životom & 4.01 & 0.47 & 3.98 & 0.51 & 0.52 \\
\hline Zadovoljstvo poslom & 4.16 & 0.59 & 4.11 & 0.69 & 0.54 \\
\hline Pozitivne emocije & 3.82 & 0.53 & 3.85 & 0.50 & -0.35 \\
\hline Negativne emocije & 1.73 & 0.56 & 1.68 & 0.56 & 0.57 \\
\hline
\end{tabular}

$* p<.05$.

Tablica 5.

Razlike između učitelja s obzirom na godine radnoga iskustva

\begin{tabular}{|c|c|c|c|c|c|}
\hline & \multicolumn{2}{|c|}{$\begin{array}{l}\leq 10 \text { god. } \\
(N=98)\end{array}$} & \multicolumn{2}{|c|}{$\begin{array}{l}>10 \text { god. } \\
(N=156)\end{array}$} & \multirow[t]{2}{*}{$t$ - test } \\
\hline & $M$ & $S D$ & $M$ & $S D$ & \\
\hline \multicolumn{6}{|l|}{ Pristupi poučavanju } \\
\hline usmjeren na učitelja & 4.05 & 0.39 & 4.16 & 0.41 & $-2.00^{*}$ \\
\hline usmjeren na učenika & 4.07 & 0.36 & 4.21 & 0.34 & $-2.93^{*}$ \\
\hline \multicolumn{6}{|l|}{ Samoefikasnost učitelja } \\
\hline angažiranost & 3.92 & 0.49 & 4.06 & 0.45 & $-2.34^{*}$ \\
\hline strategije poučavanja & 4.11 & 0.52 & 4.27 & 0.47 & $-2.58^{*}$ \\
\hline upravljanje razredom & 4.14 & 0.56 & 4.28 & 0.53 & $-1.97^{*}$ \\
\hline Zadovoljstvo životom & 3.93 & 0.47 & 4.03 & 0.50 & -1.68 \\
\hline Zadovoljstvo poslom & 4.21 & 0.63 & 4.08 & 0.65 & 1.58 \\
\hline Pozitivne emocije $^{1}$ & 3.80 & 0.50 & 3.85 & 0.52 & -0.81 \\
\hline ponos & 3.90 & 0.78 & 4.09 & 0.72 & $-1.10^{*}$ \\
\hline budnost & 3.69 & 0.88 & 3.95 & 0.81 & $-2.38^{*}$ \\
\hline Negativne emocije $^{1}$ & 1.70 & 0.58 & 1.71 & 0.55 & -0.06 \\
\hline prestrašenost & 1.82 & 0.84 & 1.60 & 0.75 & $2.11^{*}$ \\
\hline
\end{tabular}

${ }^{*} p<.05 ;{ }^{* *} p<.01 ;{ }^{1}$ prikazuju se pojedinačno samo one emocije na kojima je dobivena značajna razlika

Rezultati pokazuju da učitelji s više od 10 godina radnoga iskustva (u odnosu na one s deset i manje godina iskustva) imaju više vrijednosti u oba pristupa poučavanju i u sve tri dimenzije samoefikasnosti. Oni, također, češće osjećaju ponos i budnost. S druge strane, oni s manje od 10 godina češće se osjećaju prestrašeno. 


\section{Rasprava}

Cilj je ovog istraživanja bio ispitati koje pristupe poučavanja prihvaćaju učitelji, koliko su samoefikasni, zadovoljni poslom i životom te koje emocije doživljavaju. S obzirom na to da se pristup poučavanju usmjeren na učitelja smatra tradicionalnim pristupom, a pristup usmjeren na učenika suvremenim, očekivalo se da će veći dio učitelja prihvaćati pristup usmjeren na učenika. Rezultati su ovog istraživanja pokazali da učitelji prihvaćaju oba pristupa poučavanju. Iako dosadašnja istraživanja upućuju na nužnost promjena pristupa učitelja u radu s učenicima, čini se da do tih promjena može doći tek aktivno osmišljenim edukacijama učitelja. Primjerice, na tvrdnju Poučavanje organiziram na način koji će im (učenicima) pomoći da što bolje riješe zadatke za provjeru čak $90.6 \%$ učitelja odgovara slaganjem i slaganjem u potpunosti. Vjerojatno je ustaljen način rada, temeljen na strogoj realizaciji nastavnog plana i obrazovnih postignuća zadanih nastavnim programom, smanjio želje i mogućnosti učitelja da utječu na proširivanje znanja i interesa učenika. Davanje bi veće slobode učiteljima u kreiranju nastavnog programa omogućilo uvođenje novosti kojima su okruženi. Brualdi (1998; prema Hattie, 2012) je izbrojao da učitelji učenicima dnevno postave između dvjesto i tristo pitanja, ali većina tih pitanja ima nisku kognitivnu vrijednost. Čak $60 \%$ pitanja odnosi se na reprodukciju činjenica, a $20 \%$ na procedure. Za učitelje takva pitanja predstavljaju poveznicu između nastavnih sadržaja i ne posvećuju im dovoljnu pažnju. Učitelj na odgovor učenika čeka otprilike jednu sekundu; boljim se učenicima daje više vremena za odgovor, dok onim slabijima manje iako im je objektivno potrebno više. Hattie (2012) ističe kako je za optimalan razvoj svih učenika potrebno da učitelji pažljivo oblikuju pitanja kako bi se potaknula diskusija među učenicima u kojoj bi oni razvijali vlastite strategije. Kontinuirano uvođenje pozitivnih promjena, uz prisutno poštivanje potreba, interesa i sposobnosti učenika, sigurno bi dovelo do njihove bolje pripremljenosti za kasniji život.

Rezultati pokazuju da učitelji visoko procjenjuju vlastitu samoefikasnost, posebice u dimenzijama strategije poučavanja i upravljanje razredom. Uvjerenje učitelja o vlastitoj sposobnosti da upravlja razredom te potiče i održava pažnju i sudjelovanje učenika smatra se preduvjetom uspješne nastave (Marzano, Marzano i Pickering, 2003). Visoke procjene samoefikasnosti učitelja dobivene u ovom istraživanju predstavljaju razlog za optimizam jer narušena razredna disciplina negativno utječe na sve sudionike nastavnog procesa.

Rezultati su pokazali da su ispitivani učitelji općenito zadovoljni svojim životom, nešto zadovoljniji svojim poslom te doživljavaju dosta pozitivnih, a manje negativnih emocija. Pozitivne emocije učitelja imaju višestruku važnost, one utječu na njihovo zdravlje uglavnom tako što poništavaju utjecaj negativnih emocija, poboljšavaju kognitivnu aktivnost, ali se i prenose na učenike te se može zaključiti da će dobro raspoloženje učitelja rezultirati boljim raspoloženjem učenika (Miljković i Rijavec, 2009). Iako je logično pretpostaviti da će sposobni učitelji koji rade na 
razvoju svojih vještina biti učinkoviti u svom poslu te njime zadovoljni, neka istraživanja pokazuju da to nije sasvim dovoljno; neki ljudi razviju odgovarajuće strategije i optimalno obavljaju svoj posao, no nerijetko doživljavaju nezadovoljstvo tim istim poslom (Kinman i Jones, 2008).

Ovim se istraživanjem nastojalo ispitati postoje li razlike između učitelja s obzirom na njihov pristup poučavanju. Pretpostavilo se da će učitelji s pristupom usmjerenim na učenika pokazati veću samoefikasnost, da će doživljavati više pozitivnih nego negativnih emocija te da su zadovoljniji svojim poslom i životom. Rezultati su pokazali da se učitelji s pristupom usmjerenim na učenika statistički značajno razlikuju od učitelja s pristupom usmjerenim na učitelja u strategijama poučavanja. Utvrđena se razlika može objasniti činjenicom da pristup poučavanja usmjeren na učenika stavlja učenika u središte nastavnih aktivnosti. Pritom je zadaća učitelja pomoći učeniku u procesu učenja, a to se najlakše postiže primjenom različitih metoda poučavanja. S druge strane, strategije poučavanja, kao dimenzija samoefikasnosti, uključuje sposobnost učitelja da oblikuje raznovrsna, poticajna pitanja, sposobnost primjene različitih načina poučavanja, primjenu alternativnih strategija poučavanja i sl. Utvrđena statistički značajna razlika između promatranih skupina u skladu je s rezultatima ranijih istraživanja (Cao, Postareff, Lindblom i Toom, 2018; Temitz i Topcu, 2013) u kojima je utvrđeno kako pristup poučavanju utječe na samoefikasnost učitelja. Što je veći pristup usmjeren na učenika, to je veća samoefikasnost učitelja (Cao i sur., 2018). U istim je istraživanjima pokazano kako samoefikasnost ima velik i pozitivan utjecaj na izbor pristupa poučavanja usmjeren prema učeniku. Osim toga, pokazalo se da pristup poučavanju usmjeren na učenika i samoefikasnost imaju recipročan odnos; učitelji s visokim uvjerenjem u vlastite sposobnosti poučavanja češće se i snažnije angažiraju u stvaranju kvalitetne interakcije s učenicima (Guskey, 1988; Temiz i Topcu, 2013). Rezultati pokazuju da se učitelji s pristupom usmjerenim na učenika ne razlikuju od učitelja s pristupom usmjerenim na učitelja u doživljavanju pozitivnih i negativnih emocija. Ipak, dodatnim se provjerama za svaku emociju zasebno pokazalo da učitelji s pristupom usmjerenim na učenika češće doživljavaju zainteresiranost, uzbuđenost i budnost. S obzirom na to da su učitelji s pristupom usmjerenim na učenika više zaokupljeni time što učenik radi i u većoj su interakciji s učenicima, takvi su rezultati očekivani. Općenito se smatra se da su učitelji s pristupom usmjerenim na učenika više motivirani i entuzijastični oko svog posla, pa unatoč tome što se možda ponekad osjećaju nedovoljno uspješni u radu s učenicima, ipak imaju pozitivnije stavove prema poučavanju u cjelini (Cao i sur., 2018). Realno je pretpostaviti da takvi učitelji postižu ili barem osjećaju da postižu dobre rezultate u radu te su time i zadovoljniji svojim poslom. Ipak, u ovom istraživanju nisu utvrđene statistički značajne razlike u zadovoljstvu poslom i životom u cjelini. Mogući se razlog za ovakve rezultate nalazi u varijablama koje nisu obuhvaćene ovim istraživanjem, poput plaće, društvenog statusa i sl., a koje su možda utjecale na ovakve percepcije zadovoljstva poslom i životom. 
Sljedeći je problem ovog istraživanja bio ispitati razlikuju li se učitelji u ispitivanim varijablama s obzirom na radno mjesto. Budući da učitelji razredne nastave još od samog upisa na učiteljski studij znaju da žele raditi kao učitelji - za razliku od učitelja predmetne nastave od kojih su neki, posve sigurno, imali druge profesionalne planove u okviru svoje struke, pretpostavilo se da će učitelji razredne nastave $u$ većoj mjeri iskazivati orijentaciju na učenike, biti zadovoljniji poslom $i$ životom općenito te doživljavati više pozitivnih emocija. Dobiveni rezultati (Tablica 4.) jedinu značajnu razliku pokazuju po pitanju angažiranosti, kao komponente samoefikasnosti (veću angažiranost pokazuju učitelji razredne nastave). Iako se od svih učitelja očekuje da, između ostaloga, budu motivatori, pomažu im u radu i uče ih vrednovanju vlastita rada, te da surađuju s roditeljima s ciljem da pomognu svojoj djeci, svakodnevna praksa pokazuje da su upravo to karakteristike koje više obilježavaju učitelje razredne nastave. Osnovni je razlog dob djece koju ti učitelji poučavaju; od samog polaska u školu, susreta s novim načinom rada, suočavanje s novim obvezama, doživljavanje prvih uspjeha i neuspjeha, djeca te dobi traže neprestan učiteljev angažman. S druge strane, učenici starije dobi, iako i dalje trebaju pažnju i nadzor svojih učitelja, ipak su naučeni nositi se s novim izazovima, pa je moguće da njihovi učitelji zbog toga ne osjećaju tako veliku angažiranost.

Treći je problem istraživanja bio ispitati postoje li razlike između učitelja s obzirom na njihovo radno iskustvo. Polazna je pretpostavka bila da će učitelji s više godina radnoga iskustva biti u poučavanju više usmjereni na učenike, da će višom percipirati svoju samoefikasnost, da će biti zadovoljniji poslom i životom te da će doživljavati više pozitivnih nego negativnih emocija (jer su, dijelom zbog toga, u pozivu i ostali duže od 10 godina). Rezultati su pokazali da učitelji s više od deset godina iskustva, u odnosu na učitelje s manje radnoga iskustva, više koriste oba pristupa. Čini se da radno iskustvo pomaže u oblikovanju učiteljeva pristupa poučavanju, ali ne definira hoće li iskusniji učitelji više koristiti pristup usmjeren na učenika ili pristup usmjeren na sebe. Dok dio autora smatra da je pristup poučavanju relativno stabilan kroz vrijeme (Kamber i Kwan, 2000), te da ga je jako teško mijenjati (Kember, 1997), neki drugi (npr. Trigwell i Prosser, 1996a) smatraju da isti učitelji mogu ponekad koristiti pristup usmjeren na učitelja, a ponekad pristup usmjeren na učenika ovisno o situaciji u kojoj se nalaze. U tom je kontekstu moguće objasniti i rezultate ovog istraživanja.

U skladu s očekivanjima, iskusniji učitelji značajno višom procjenjuju svoju samoefikasnost u sve tri njezine dimenzije: angažiranost, strategije poučavanja i upravljanje razredom. Ovi su rezultati u skladu s rezultatima ranijih istraživanja (Tschannen-Moran i Woolfolk Hoy, 2007), a mogu se objasniti povezanošću ranijih uspjeha učitelja s njihovim osjećajem samoefikasnosti. Naime, istraživanja pokazuju da učitelji na početku svoje karijere imaju određen osjećaj samoefikasnosti koji s vremenom raste ako učitelj osjeća da postiže rezultate u radu. Upravo ti raniji uspjesi u poučavanju dovode do većeg samopouzdanja i samoefikasnosti (Tschannen-Moran i Woolfolk Hoy, 2007). 
Premda se, u cjelini, učitelji ne razlikuju u doživljavanju pozitivnih i negativnih emocija, analizom se rezultata za svaku pojedinačnu emociju pokazalo da iskusniji učitelji češće doživljavaju ponos i budnost, a da su oni s manje radnog iskustva češće prestrašeni. Ovakvi se rezultati mogu povezati upravo s ranijim postignućima učitelja: učitelji koji postižu dobre rezultate u radu s učenicima vrlo vjerojatno će se zbog toga biti ponosni (a i ostat će u pozivu) i logično je da će s više radnoga iskustva imati više pozitivnih iskustava i uspjeha zbog kojih se mogu osjećati ponosno. Strah je negativna emocija koja se pokazala vrlo čestom kod učitelja na početku radnoga staža (Sutton i Wheatley, 2003; Tickle, 1991). Učitelji s manje godina radnoga iskustva najčešće osjećaju strah zbog komunikacije s roditeljima te zbog nesigurnosti rade li svoj posao dobro ili ne. Zbog toga je za mlađe učitelje korisno organizirati stručnu kolegijalnu pomoć starijih, iskusnijih učitelja.

\section{Zaključak}

Istraživanje potvrđuje mnoge prethodne spoznaje o važnosti istraživanja pristupa poučavanju, samoefikasnosti, zadovoljstva poslom i životom učitelja te povezanosti s pozitivnim i negativnim emocijama. Prilikom interpretacije rezultata važno je uzeti u obzir nekoliko čimbenika koji mogu ograničiti generalizaciju opisanih nalaza. Prije svega, istraživanje je provedeno na prigodnom uzorku: sudionici su bili samo učitelji iz Zagreba, dominantno učiteljice. Ipak, dobiveni rezultati pružaju nove spoznaje o povezanosti pristupa poučavanja, samoefikasnosti, emocija i zadovoljstva poslom i životom učitelja. Osim znanstvenog doprinosa ovog istraživanja, rezultati upućuju i na potrebu da se u praksi osigura veća podrška učiteljima na početku njihove karijere. $\mathrm{S}$ obzirom na to da pristup usmjeren na učenika podrazumijeva pozicioniranje učenika u središte pozornosti nastavnog procesa, a takvim se pristupom omogućuje bolje razumijevanje te olakšava proces učenja, čime učenici postaju aktivni sudionici i pokazuju veću zainteresiranost za učenje, u praksi bi trebalo češće provoditi edukacije učitelja kako bi ovaj pristup bio još prihvaćeniji od strane učitelja. Dakle, rezultati ovog istraživanja mogu biti temelj za razvoj savjetodavnih i edukativnih programa koji će poticati prihvaćanje novih pristupa i strategija poučavanja, a što može poticati osjećaj samoefikasnosti učitelja te povećati njihovo zadovoljstvo i češće doživljavanje pozitivnih emocija.

\section{Literatura}

Allinder, R. (1994). The relationship between efficacy and the instructional practices of special education teachers and consultants. Teacher Education and Special Education, 17, 86-95. doi:10.1177/088840649401700203 
Anderson, R., Greene, M. i Loewen, P. (1988). Relationships among teachers' and students' thinking skills, sense of efficacy, and student achievement. Alberta Journal of Research, 34(2), 148-165.

Ashton, P. i Webb, R. (1986). Making a difference: Teacher's sense of self-efficacy and student achievement. New York: Longman.

Bandura, A. (1997). Self-efficacy: The exercice of control. New York: Freeman.

Beard, R. i Senior, I. (1980). Motivating students. London: Routledge and Kegan Paul.

Becker, E., Goetz, T., Morger, V. i Ranellucci, J. (2014). The importance of teachers' emotions and instructional behavior for their students' emotions - an experience sampling analysis. Teaching and Teacher Education, 43, 15-26. doi:10.1016/j.tate. 2014.05.002

Beilock, S., Gunderson, E., Ramirez, G. i Levine, S. (2010). Female teachers' math anxiety affects girls' math achievement. PNAS, 207(5), 1860-1863. doi:10.1073/pnas. 0910967107

Biddle, S. i Goudas, M. (1997). Effort is virtuous: Teacher preferences of pupil effort, ability and grading in physical education. Educational Research, 39, 350-355. doi:10.1080/ 0013188970390310

Bryk, A. i Schneider, B. (2002). Trust in schools: A core resource for improvement. New York: Russell Sage Foundation.

Cao, Y., Postareff, L., Lindblom, S. i Toom, A. (2018). Teacher educators' approaches to teaching and the nexus with self-efficacy and burnout: Examples from two teachers' universities in China. Journal of Education for Teaching, 44(4), 479-495. doi:10.1080/026074

Chang, M. L. (2009). An appraisal perspective of teacher burnout: Examining the emotional work of teacher. Educational Psychological Review, 21, 193-218. doi:10.1007/s10648009-9106-y

Chang, M. L. (2013). Toward a theoretical model to understand teacher emotions and teacher burnout in the context of student misbehavior: Appraisal, regulation and coping. Motivation and Emotion, 37(4), 799-817. doi:10.1007/s11031-012-9335-0

Coladarci, T. (1992). Teachers' sense of efficacy and commitment to teaching. Journal of Experimental Education, 60, 323-337. doi:10.1080/00220973.1992.9943869

Darby, A. (2008). Teachers' emotions in the reconstruction of professional selfunderstanding. Teaching and Teacher Education, 24, 1160-1172. doi:10.1016/j.tate. 2007.02.001

Debnath, S. C. (2005). College student motivation: An interdisciplinary approach to an integrated learning systems model. Journal of Behavioral and Applied Management, 6(3), 168-189.

Diener, E. i Emmons, R. (1984). The independence of positive and negative affect. Journal of Personality and Social Psychology, 47, 1105-1117. doi:10.1037/0022-3514.47.5. 1105 
Diener, E., Emmons, R., Larsen, R. i Griffin, S. (1985). The satisfaction with life scale. Journal of Personality Assessment, 49(1), 71-75. doi:10.1207/s15327752jpa4901_13

D'Souza, K. A. i Maheshwari, S. K. (2010). Factors influencing student performance in the introductory management science course. Academy of Educational Leadership Journal, 14(3), 99-120.

Duckworth, A. L., Quinn, P. D. i Seligman, M. E. (2009). Positive predictors of teacher effectiveness. The Journal of Positive Psychology, 4(6), 540-547. doi:10.1080/ 17439760903157232

Frenzel, A. C. (2014). Teacher emotions. U: L. Linnenbrink-Garcia i R. Pekrun (Ur.), Handbook of emotions in education (str. 494-519). New York: Routledge.

Frenzel, A. C., Goetz, T., Lüdtke, O., Pekrun, R. i Sutton, R. E. (2009). Emotional transmission in the classroom: Exploring the relationship between teacher and student enjoyment. Journal of Educational Psychology, 101, 705-716. doi:10.1037/a0014695

Gibson, S. i Dembo, M. (1984). Teacher efficacy: A construct validation. Journal of Educational Psychology, 76, 569-582. doi:10.1037/0022-0663.76.4.569

Guskey, T. R. (1988). Teacher efficacy, self, concept, and attitudes toward the implementation of instructional innovation. Teaching and Teacher Education, 4(1), 6369. doi:10.1016/0742-051X(88)90025-X

Hargreaves, A. (1998). The emotional practice of teaching. Teaching and Teacher Education, 14(8), 835-854. doi:10.1016/S0742-051X(98)00025-0

Hargreaves, A. (2000). Mixed emotions: Teachers' perceptions of their interactions with students. Teaching and Teacher Education, 16(8), 811-826. doi:10.1016/S0742051X(00)00028-7

Hargreaves, A. i Tucker, E. (1991). Teaching and guilt: Exploring the feelings of teaching. Teaching and Teacher Education, 7(5-6), 491-505. doi:10.1016/0742-051X(91)90044-P

Hattie, J. (2012). Visible learning for teachers: Maximizing impact on learning. New York: Routlege.

Ingersoll, R. (2003). Is there really a teacher shortage? Philadelphia, PA: University of Pennsylvania, Consortium for Policy Research in Education.

Kamber, D. i Kwan, K. (2000). Lecturers' approaches to teaching and their relationships to conceptions of good teaching. Instructional Science, 28(5), 469-490. doi:10.1023/A: 1026569608656

Keller, M., Chang, M., Becker, E., Goetz, T. i Frenzel, A. (2014). Teachers' emotional experiences and exhaustion as predictors of emotional labor in the classroom: An experience sampling study. Frontiers in Psychology, 5(1442). doi:10.3389/fpsyg. 2014.01442

Kember, D. (1997). A reconceptualisation of the research into university academics' conceptions of teaching. Learning and Instruction, 7, 255-275. doi:10.1016/S09594752(96)00028-X 
Kinman, G. i Jones, F. (2008). Effort-reward imbalance and over commitment: Predicting strain in academic employees in the United Kingdom. International Journal of Stress Management, 15(4), 381-395. doi:10.1037/a0013213

Lyubomirsky, S., King, L. i Diener, E. (2005). The benefits of frequent positive affect: Does happiness lead to success? Psychological Bulletin, 131, 803-855. doi:10.1037/00332909.131.6.803

Macuka, I., Burić, I. i Slišković, A. (2017). Emocionalna iskustva učitelja kao prediktori njihova mentalnoga zdravlja. Psihologijske teme, 26(2), 355-375.

Marlow, L., Inman, D. i Betancourt-Smith, M. (1996). Teacher job satisfaction. ERIC Document Reproduction Service, No. ED 393802.

Marton, F. i Säljö, R. (1976). On qualitative differences in learning I. Outcome and process. British Journal of Eductional Psychology, 46, 4-11. doi:10.1111/j.2044-8279.1976. tb02980.x

Marzano, R. J., Marzano, J. S. i Pickering, D. J. (2003). Classroom management that works: Research-based strategies for every teacher. Alexandria, VA: Association for Supervision and Curriculum Development.

Matzler, K. i Renzl, B. (2006). The relationship between interpersonal trust, employee satisfaction, and employee loyalty. Total Quality Management, 10, 1261-1271. doi:10.1080/14783360600753653

Midgley, C., Feldlaufer, H. i Eccles, J. (1989). Change in teachre efficacy and student selfand task-related beliefs in mathematics during the transition to junior high school. Journal of Educational Psychology, 81, 247-258. doi:10.1037/0022-0663.81.2.247

Miljković, D. i Rijavec, M. (2007). What makes teachers happy? Quantitative and qualitative aspects of job satisfaction and psychological well-being of teachers. U: M. Cindrić (Ur.), Pedagogija u kontekstu društva znanja (str. 41-47). Zagreb: ENCSI i UFZG.

Miljković, D. i Rijavec, M. (2009). Važnost pozitivnih emocija u odgoju i obrazovanju. Napredak, 150(3-4), 488-506.

Miljković, D., Jurčec, L. i Rijavec, M. (2016). The relationship between teachers' work orientations and well-being with mediating effects of work meaningfulness and occupational identity. U: Z. Marković, M. Đurišić Bojanović i G. Đigić (Ur.), The relationship between teachers' work orientations and well-being with mediating effects of work meaningfulness and occupational identification. Individual and environment: International thematic proceedia (str. 303-312). Niš: Univerzitet u Nišu, Filozofski fakultet.

Moolenaar, N. i Sleegers, P. (2010). Social networks, trust, and innovation. How social relationships support trust and innovative climates in Dutch schools. U: A. J. Daly (Ur.), Social network theory and educational change (str. 97-115). Cambridge, MA: Harvard University Press.

Palmer, D. (2007). What is the best way to motivate students in science? Teaching Science: The Journal of the Australian Science Teachers Association, 53(1), 38-42. 
Pavin Ivanec, T. (2008). Odrednice pristupa učenju $i$ poučavanju u srednjoškolskom kontekstu. (Neobjavljena doktorska disertacija). Zagreb: Filozofski fakultet Sveučilišta u Zagrebu.

Pavin, T., Rijavec, M. i Miljević-Riđički, R. (2005). Percepcija kvalitete obrazovanja učitelja i nastavnika i nekih aspekata učiteljske i nastavničke profesije iz perspektive osnovnoškolskih učitelja i nastavnika. U: V. Vizek Vidović, V. Vlahović-Štetić, T. Pavin, M. Rijavec, R. Miljević-Riđički i A. Žižak (Ur.), Cjeloživotno obrazovanje učitelja i nastavnika: Višestruke perspektive (str. 92-125). Zagreb: Institut za društvena istraživanja u Zagrebu.

Pavot, W. i Diener, E. (1993). Review of the Satisfaction with life scale. Psychological Assessment, 5(2), 164-172. doi:10.1037/1040-3590.5.2.164

Pekrun, R., Goetz, T., Titz, W. i Perry, R. (2002). Academic emotions in students' selfregulated learning and achievement: A program of qualitative and quantitative research. Educational Psychology, 37, 95-105. doi:10.1207/S15326985EP3702_4

Postareff, L. i Lindblom-Ylänne, S. (2008). Variation in teachers' descriptions of teaching: Broadening the understanding of teaching in higher education. Learning and Instruction, 18, 109-120. doi:10.1016/j.learninstruc.2007.01.008

Prosser, M. i Trigwell, K. (1997). Relations between perceptions of the teaching environment and approaches to teaching. British Journal of Educational Psychology, 67, 25-35. doi:10.1111/j.2044-8279.1997.tb01224.x

Prosser, M. i Trigwell, K. (1998). Understanding learning and teaching: The experience in higher education. Milton Keynes: Open University Press.

Ramsden, P. (1992). Learning to teach in higher education. London: Routledge.

Rijavec, M., Pečjak, S., Jurčec, L. i Gradišek, P. (2016). Money and career or calling? Intrinsic vs. extrinsic work orientations and job satisfaction of Croatian and Slovenian teachers. Croatian Journal of Education, 18(1), 201-223. doi:10.15516/cje.v18i1.1163

Ross, J. (1992). Teacher efficacy and the effect of coaching on student achievement. Canadian Journal of Education, 17(1), 51-65. doi:10.2307/1495395

Scarpello, V. i Campbell, J. P. (1983). Job satisfaction: Are all the parts there? Personnel Psychology, 36(3), 577-600. doi:10.1111/j.1744-6570.1983.tb02236.x

Shin, L. i Johnson, D. (1978). Avowed happiness as an overall assessment of the quality of life. Social Indicators Research, 5, 475-492. doi:10.1007/BF00352944

Slišković, A., Burić, I. i Knežević, I. (2016). Zadovoljstvo poslom i sagorijevanje na poslu kod učitelja: Važnost podrške ravnatelja i radne motivacije. Društvena istraživanja, 25(3), 371-392. doi:10.5559/di.25.3.05

Stein, M. i Wang, M. (1988). Teacher development and school improvement: The process of teacher change. Teaching and Teacher Education, 4, 171-187. doi:10.1016/0742-051X (88)90016-9

Sutton, R. (2005). Teachers' emotions and classroom effectiveness: Implications from recent research. The Clearing House, 78(5), 229-234. 
Sutton, R. (2007). Teachers' anger, frustration, and self-regulation. U: P. Schutz i R. Pekrun (Ur.), Emotion in education (str. 251-266). San Diego: AcademicPress. doi:10.1016/ B978-012372545-5/50016-2

Sutton, R. i Wheatley, K. (2003). Teachers' emotions and teaching: A review of the literature and directions for future research. Educational Psychology Review, 15, 327-358. doi:10.1023/A:1026131715856

Temiz, T. i Topcu, M. S. (2013). Preservice teachers' teacher efficacy beliefs and constructivist-based teaching practice. European Journal of Psychology of Education, 28(4), 1435-1452. doi:10.1007/s10212-013-0174-5

Tickle, L. (1991). New teachers and the emotions of learning teaching. Cambridge Journal of Education, 21(3), 231-329. doi:10.1080/0305764910210306

TIMSS \& PIRLS. (2016). Teacher job satisfaction. Preuzeto s http://timssandpirls.bc.edu/ timss2015/international-results/timss-2015/mathematics/school-climate/teacher-jobsatisfaction/

Trigwell, K. i Prosser, M. (1991). Improving the quality of student learning: The influence of learning context and student approaches to learning on learning outcomes. Higher Education, 22(3), 251-266. doi:10.1007/BF00132290

Trigwell, K. i Prosser, M. (1996a). Changing approaches to teaching: A relational perspective. Studies in Higher Education, 21, 275-284. doi:10.1080/03075079612331381211

Trigwell, K. i Prosser, M. (1996b). Congruence between intention and strategy in university science teachers' approaches to teaching. Higher Education, 32, 77-87. doi:10.1007/ BF00139219

Trigwell, K. i Prossser, M. (2004). Development and use of the Approaches to teaching inventory. Educational Psychology Review, 16(4), 409-424. doi:10.1007/s10648-0040007-9

Trigwell, K., Prosser, M. i Ginns, P. (2005). Phenomenographic pedagogy and a revised "Approaches to teaching inventory". Higher Education Research i Development, 24(4), 349-360. doi:10.1080/07294360500284730

Trigwell, K., Prosser, M. i Taylor, P. (1994). Qualitetive differences in approaches to teaching first year university science. Higher Eduaction, 27, 75-84. doi:10.1007/BF01383761

Trigwell, K., Prosser, M. i Waterhouse, F. (1999). Relations between teachers' approaches to teaching and students' approaches to learning. Higher Education, 37(1), 57-70. doi:10.1023/A:1003548313194

Tschannen-Moran, M. i Woolfolk Hoy, A. (2001). Teacher efficacy: Capturing and elusive construct. Teaching and Teacher Education, 17(7), 783-805. doi:10.1016/S0742051X(01)00036-1

Tschannen-Moran, M. i Woolfolk Hoy, A. (2007). The differential antecedents of selfefficacy beliefs of novice and experienced teachers. Teaching and Teacher Education, 23, 944-956. doi:10.1016/j.tate.2006.05.003 
Tschannen-Moran, M., Woolfolk Hoy, A. i Hoy, W. (1998). Teacher efficacy: Its meaning and measure. Review of Educational Research, 68(2), 202-248. doi:10.3102/ 00346543068002202

Van Maele, D. i Van Houtte, M. (2012). The role of teacher and faculty trust in forming teacher's job satisfaction: Do years of experience make a difference? Teaching and Teacher Education, 28, 879-889. doi:10.1016/j.tate.2012.04.001

Van Rossum, E. i Schenk, S. (1984). The relationship between learning conception, study strategy and learning outcome. British Journal of Educational Psychology, 54, 73-83. doi:10.1111/j.2044-8279.1984.tb00846.x

Vidić, T. (2009). Zadovoljstvo poslom učitelja u osnovnoj školi. Napredak, 150(1), 7-20.

Watson, D., Clark, L. i Tellegen, A. (1988). Development and validation of Brief Measures of Positive nad Negative Affect: The PANAS Scales. Journal od Personality and Social Psychology, 54(6), 1063-1070. doi:10.1037/0022-3514.54.6.1063

\title{
Relationship between Approaches to Teaching, Self-Efficacy, Life and Job Satisfaction, and Emotions in Elementary School Teachers
}

\begin{abstract}
The aim of this study was to examine the relationship between approaches to teaching, teacher selfefficacy, life and job satisfaction and emotions. The study included 254 teachers from eight elementary schools in Zagreb. The results showed significant correlations between approaches to teaching and all three dimension of teacher self-efficacy (engagement, teaching strategies, classroom management). Job satisfaction is significantly related to the life satisfaction and positive emotions. Negative emotions are negatively related to life as well as job satisfaction. Teachers with studentcentered approach, compared with those teacher-centered, have a higher self-efficacy (in the dimension teaching strategy) and are more likely to experience positive emotions: interest, excitement, and attention. Lower grades teachers demonstrated greater engagement than higher grades teachers. Teachers with more than ten years of work, compared with those less experienced, have a higher student-centered approach and a higher teacher-centered approach and are more likely to experience pride and vigilance. On the other hand, teachers with ten or less than ten years of working experience are more frightened.
\end{abstract}

Keywords: approaches to teaching, self-efficacy, life satisfaction, job satisfaction, emotions, elementary school teachers

Primljeno: 21.3.2018. 